\title{
The Roles of Hedonic Value and Fashion Consciousness in Female Shoes Purchase Context: Application of the Theory of Planned Behavior
}

\author{
Yun Wang ${ }^{1}$ \\ ${ }^{1}$ Department of Fashion Design and Management, National Pingtung University of Science and Technology, \\ Pingtung, Taiwan \\ Correspondence: Yun Wang, Department of Fashion Design and Management, National Pingtung University of \\ Science and Technology, No.1 Shuehfu Rd., Neipu, Pingtung, Taiwan. E-mail: yunw@mail.npust.edu.tw
}

Received: March 3, 2020 Accepted: April 13, 2020 Online Published: April 17, 2020

doi:10.5539/ijms.v12n2p38 URL: https://doi.org/10.5539/ijms.v12n2p38

\begin{abstract}
In Taiwan, the total annual sale of shoes is NT\$ 60 billion in which female shoes accounted for about NT\$36 billion. The purpose of this research is to examine female consumers' purchase intentions of fashion shoes by applying the Theory of Planned Behavior model. Additionally, this research incorporated hedonic shopping value as an independent variable to TPB model and examined the mediation role of fashion consciousness between dependent variables and independent variable. A total of 450 questionnaires were distributed outside department stores using Mall-intercept method in Southern cites, Taiwan. The results indicated attitude, subjective norm, behavior control, and hedonic value have positive effects on fashion consciousness and purchase intention of fashion shoes. In addition, fashion consciousness has partial mediation effects between the relationships of attitude, subjective norm, and behavior control and purchase intention of fashion shoes. Full mediation effect is found between the relationship of hedonic value and purchase intent of fashion shoes.
\end{abstract}

Keywords: hedonic value, fashion consciousness, Theory of Planned Behavior, attitude, fashion shoes

\section{Introduction}

Taiwan Female labor force participation rate exceeded 50\% in the year of 2012 and continue growth to $51.14 \%$ in 2018 (Yuan, 2018). Due to the improvement in education, decrease in the number of child carry, and the modernization of household equipment, the number of female labors increased from 4.61 million in 2010 to 5.08 million in 2018. Increase in number of working women worldwide has augmented the demand of trendy and stylish footwear, which can be used for formal as well as casual occasions. Besides, surge in disposable income is allowing individuals to spend more on luxury goods, thereby driving the growth of the footwear market. The global footwear market size was valued at $\$ 365.5$ billion in 2020 and is estimated to reach $\$ 530.3$ billion by 2027 with a CAGR of 5.5\% from 2020 to 2027 (Chouhan \& Vig, 2020). In addition, the global women's footwear was estimated market size of US\$ 152.2 billion in 2018, the value sales of women's footwear are expected to reach US\$219.5 billion by 2027, expanding at a CAGR of 4.2\% (Future Market Insights, 2018). Grand view research (2019) stated Asia Pacific was the largest regional market in 2018 and will expand further at the highest CAGR from 2019 to 2025. This mainly due to high demand for stylish and comfortable footwear. Moreover, changing consumer behavior and rising disposable income levels, especially in developing countries like China and India, are expected to propel the market growth.

The Boston Consulting Group (2012) predicts China's female economy over the next few years to grow much stronger. Young professional women will enter the middle and top management positions and fuel the next wave of growth in the luxury business. It shows women are economic independent and are the major decision makers of most consumption product purchased. Similarly, Zhou (2014) indicated China footwear market sales also dominates by women's (53\%), follow by men's (34\%) and children's (12\%). Taiwan footwear market sale was NT\$ 67 billion in year 2011 in which female shoes sales accounted for almost NT\$ 36 billion (54\%) compare to male (36\%), and children (10\%) footwear; the footwear market tends to be stable, unless people GDP grows the footwear market sales won't augment (Industrial Development Bureau, 2011). These data demonstrated that female fashion shoes in Asian accounted for a significant portion of the shoe market. O'Keeffe (1996) stated that 
each woman had average 30 pair of shoes which doubled that of male consumers. Even though government data and online market research analysts indicated that shoe consumption is important in daily life of women, no research has done to study female consumers' purchase intention of fashion shoes. Therefore, this research intends to apply the Theory of Planned Behavior model to examine the female consumers' purchase intention of fashion shoes.

The Theory of Planned Behavior (TPB), an extended model of the Theory of Reasoned Action (Ajzen, 1985, 1991; Ajzen \& Madden, 1986), is one of the most widely researched models for predicting behavioral intentions by social psychologists (Armitage \& Conner, 2010; Fielding, Terry, Masser, \& Hogg, 2008; Vermeir \& Verbeke, 2008; Yang, 2012). Kim and Karpova (2010) conducted a research of consumer attitudes toward fashion counterfeits by apply the TPB model. They found female college students' attitude, subjective norm, and perceived behavioral controls are significant factors to the counterfeit goods purchase intention in the United States. Other studies extended the TPB with other determinant factors into their research models. For example, Chen and Tung (2014) built a model that incorporates moral norms and consequences of recycling to explain consumers' recycling intentions and found that this extended TPB research model could explain consumers' recycling intentions well. Fogel and Zachariah (2017) used TPB in reading online reviews research and found that increased brand trust and increased number of reviews read were each associated with both increased intentions and behavior. Correct knowledge of online review fraud and those who previously wrote Yelp reviews were each associated with increased behavior. In this study we first apply the TPB model which includes consumers' attitude toward fashion shoes, subjective norms, and perceived behavioral control to study consumers' intention to purchase fashion shoes. In the literature, the fashion consciousness refers to the extent a consumer is caught up with fashion styles or clothing. It is merely one's desire for and adoption of up-to-date styles to maintain one's status in a social network (Lertwannawit \& Mandhachitara, 2012; Nam et al., 2007; Shim \& Gehrt, 1996.). Further, studies have demonstrated that hedonic value is tied to behavioral intention (Chang, Burns, \& Francis, 2004; Davis, Lang, \& San Diego, 2014; Jayawardhena \& Wright, 2009; Jones, Reynolds, \& Arnold, 2006). We then extended the TPB model to include hedonic shopping value as independent variable and the fashion consciousness as mediator in our study of fashion shoes purchase context.

\section{Literature Review and Hypotheses}

\subsection{Theory of Planned Behavior Framework}

The TPB proposed by Ajzen (1991) is a widely accepted social-psychology theory which suggests that intention is a direct precursor to behavior (Bagozzi, Baumgartner, \& Yi, 1989). TPB has been applied to studies in various domains such as advertising, public relations, information technology, and healthcare. In short, the TPB suggests that beliefs and their corresponding attitudes influence intentions, which drives actual behavior. Specifically, intentions are in turn determined by three factors related to the behavior: the person's attitude, subjective norms, and perceived behavioral control. Attitude (ATT) is defined as the psychological emotion and the positive or negative evaluation that arises when an individual engages in certain behaviors (Eagly \& Chaiken, 1993). Fishbein and Ajzen (1975) posit that, in the consumer's decision-making process, an attitude towards a behavior is a direct predictor to the behavioral intention. This positive relationship between attitude and purchase intent (PI) has received support across different products and services. For example, Bellman, Teich, and Clark (2009) found that fashion accessory buying intentions are affected by young female shoppers' attitudes towards purchasing fashion accessories. Bian and Forsythe (2012) found that both U.S. and Chinese consumers' attitudes toward luxury brands positively influence their purchase intention of luxury brand. Additionally, attitudes positively affect intentions to recycle (Culiber, 2014).

In line with the TPB (Ajzen, 1991), social pressure played on an individual by certain others also plays an important role in the purchase of fashion goods as they help in maintaining certain relationships. Ajzen (1991) defined subjective norms ( $\mathrm{SN}$ ) as the degree of social pressure felt by a person about the behavior. It is these social pressures that force consumers to perform certain acts to be able to gain approval in various social situations. When examining the relationship between people's subjective norms and behavioral intention, it is confirmed that subjective norms positively affect behavioral intention (Taylor \& Todd, 1995). Fernandes (2013) conducted a research of counterfeit fashion purchase behaviour in 20-40 years old consumers in the United Arab Emirates. He found that the subjective norm is a significant factor in the counterfeit purchase intention only in the group that is more likely to purchase counterfeit.

In addition to individual's ATT and SN, perceived behavioral control (BC) should also be considered in the TPB model. BC refers to an individual's perception of the possible difficulties when performing a specific behavior (Ajzen, 1991). Some external and unpredictable factors such as time, chance, money, etc. may not be under 
control of individuals. Thus, those who perceive a higher degree of personal control tend to have stronger behavioral intention to engage in a certain behavior (Ajzen, 1991). In specific when people believe they have more resources such as time, money, or skills, their perceptions of control are high, hence their behavioral intentions increase. Based on published literature, the following hypotheses are developed:

H1a. Consumers' attitude has positive effect on their purchase intentions of fashion shoes.

H2a. Consumers' subjective norm has positive effect on their purchase intentions of fashion shoes.

H3a. Consumers' perceived behavioral control has positive effect on their purchase intentions of fashion shoes.

\subsection{Hedonic Value}

Baboin, Darden and Griffin (1994) suggested that the shopping experience provides consumers with a combination of utilitarian and hedonic shopping value. Consumers perceive utilitarian value by acquiring the product that necessitated the shopping trip while simultaneously perceiving hedonic value (HV) associated with the enjoyment of the shopping experience itself. According to Blackwell, Miniard and Engel (2000) hedonic value derived from the shopping experience reflects the emotional or psychological worth of the purchase. Sources of hedonic value could include the joy and/or the excitement of shopping, or the escape from everyday activities. The Mathwick, Malhotra, and Rigdon's (2001) experiential value scale reflects both hedonic and utilitarian benefits derived from perceptions of playfulness, esthetic appeal, consumer return on investment, and service excellence. Arnold and Reynolds (2003) developed a scale of hedonic shopping motivations consisting of six dimensions: adventure, social, gratification, idea, role, and value shopping. Carpenter (2008) found both hedonic and utilitarian values affect satisfaction, loyalty, word of mouth communication, and purchases hehavior; and they also mediate the relationships between mood regulation and word of mouth (Arnold \& Reynolds, 2009). While both dimensions are positively correlated to feelings of pleasure and arousal, hedonic values have a significantly stronger effect (Babin et al., 1994). Chen, Chang and Chen (2017) research reveals that hedonic values play a more important role than utilitarian values do in users' purchase intentions and the continued use of social commerce. It was found that quality and the feelings of interactions are antecedents of customer values. Epuran Gardan, Gardan, and Bumbas (2015) found in Romanian consumers that expensive clothing products will augment their satisfaction based on hedonic values. Meanwhile the importance of worn clothes high price has greatest influence upon the hedonic consumption based on consumption motivation related with others image upon clothes. Previous studies have provided empirical support that HV to be related to behavioral intention (Cowart \& Goldsmith, 2007; Davis et al., 2014). Besides, the category of this research involves fashion shoes which is not a necessary product and is more personal and subjective in purchase context, we would only examine the hedonic value in this research. Based on the discussions above, the following hypothesis is developed:

H4a. Consumers' hedonic value has positive effect on their fashion shoes purchase intentions.

\subsection{Fashion Consciousness}

Because of the fast pace in the fashion market, an individual must frequently reevaluate him/herself and the meanings attached to the styles that he/she has adopted to remain current (Back, 1985). This continuous process of fashion style attachment gives rise to a cycle of desire for the most unique and/or latest fashion goods. Consumers participate in this process in an attempt to resolve a never-ending feel of dissatisfaction with their current lifestyle and physical appearance (Bordo, 1993; Hourigan \& Bougoure, 2012). Thus, fashion consciousness (FC) refers to the extent to which a consumer is caught up with styles or fashion of clothing. It can be a person's degree of involvement with the styles or fashion of clothing. An individual does not have to be either a fashion opinion leader or a fashion innovator to be considered fashion conscious. Rather, fashion consciousness is characterized by an interest in clothing and fashion, and in one's appearance (Gutman \& Mills, 1982).

Parker, Hermans and Schaefer (2004) found the market differences in FC between developed countries (US and Japanese teens) and less developed countries (Chinese teens). Goldsmith, Flynn, and Kim (2010) reported a significant mediating effect of FC on the relationship between price sensitivity and status consumption. A research in Islamic marketing shows that dressing style, fashion motivation, fashion uniqueness and sources of fashion knowledge positively influence fashion consciousness and indirectly influence hijab fashion consumption (Hassan \& Harun, 2016). Using TPB as a framework, Fernandes (2013) examined how FC affects the intention of counterfeits fashion product purchase; he found that there is no significant relation between FC and PI. However, in correlation matrix table, the FC had positive significant relationship with subjective norm. 
In addition, Lertwannawit and Mandhachitara (2012) found self-monitoring and susceptibility to interpersonal influence had both direct and indirect effect on status consumption and this effect was mediated by the fashion consciousness. Regarding the fashion consciousness, we developed the following hypotheses:

H1b. Consumers' attitude has positive effect on their fashion consciousness.

H2b. Consumers' subjective norm has positive effect on their fashion consciousness.

H3b. Consumers' perceived behavioral control has positive effect on their fashion consciousness.

H4b. Consumers' hedonic value has positive effect on their fashion consciousness.

H5. Fashion consciousness has positive effect on purchase intention of fashion shoes.

H1c. Fashion consciousness mediates the relationship between consumers' attitude and their purchase intention of fashion shoes.

H2c. Fashion consciousness mediates the relationship between consumers' subjective norm and purchase intention of fashion shoes.

H3c. Fashion consciousness mediates the relationship between perceived behavior control and purchase intention.

H4c. Fashion consciousness mediates the relationship between hedonic value and purchase intention.

The research hypotheses proposed bring about consumers' purchase intention of fashion shoes model described in Figure 1. In the next section there is methodology used to test out these hypotheses.

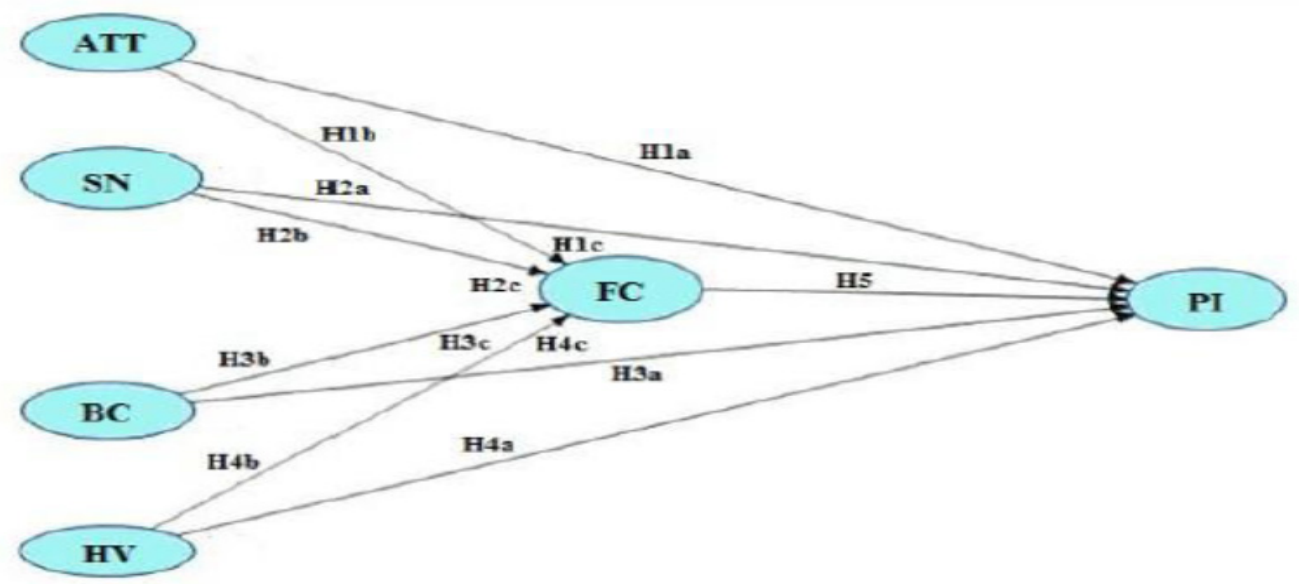

Figure 1. Fashion shoes purchase intention model

\section{Methodology}

\subsection{Measurements}

Four independent variables (IVs), one mediation variable, and one dependent variable (DV) in this study were measured using items adapted from previous studies. ATT, SN, and BC were measured based on Canniere, Pelsmacker and Geuens (2009). HV was adapted from Babin et al. (1994). FC was adapted from Lertwannawit and Mandhachitara (2012). PI was measured using three items adapted from Bhattacherjee (2000). All measurements used a 7-point Likert scale with response options ranging from 1-strongly disagree to 7-strongly agree.

\subsection{Sampling and Data Collection}

Prior studies have shown the importance of gender effect (Davis et al., 2014; Noble, Griffith, \& Adjei, 2006) in retail shopping behavior. Females derive greater levels of hedonic value and show more positive attitudes toward mall shopping in comparison to males (Jackson, Stoel, \& Brantley, 2011). Therefore, the sampling for this research is mainly female consumers. A pilot study including sixty-five female was conducted to test the clarity of wording in the questionnaire. After inform consent of the stores' managers, Mall-intercept method was used with total 450 questionnaires distributed to customers in retail stores during the months of October and December 2016. These department stores locate in Southern cites in Taiwan which are Hanshin Arena Shopping Plaza, Dream Mall, E-Da outlet Mall and Shin Kong Mitsukoshi department store. The final data analysis 
included 414 completed questionnaires and the overall response rate was $92 \%$. Most respondents are females age between $26-35$ years old $(40.5 \%)$, have education of college degree $(54.7 \%)$ and with monthly income around NT\$20,001 40,000 (39.3\%).

\subsection{Data Analysis}

Data were analyzed by using Smart Partial Least Squares (PLS) 2.0. The PLS model is analyzed and interpreted in two stages. First, the adequacy of the measure is assessed by evaluating the reliability of the measurement model and the discriminant validity of the constructs by applying standard decision rules. Research stated composite reliability (CR) and Cronbach alpha of constructs must be larger than the proposed threshold .70 (Nunally \& Bernstein, 1994). Convergent validity which obtained by the average variance extracted (AVE) need to larger than the proposed threshold .50 (Fornell \& Larcker, 1981). Discriminant validity was obtained from (1) each indicator's loading is higher for its designated construct than for any of the other constructs, and each of the constructs loads highest with its assigned items (Chin, 1998) which was the case for all the indicators; (2) the square root of AVE were greater than the correlations between the construct and other constructs in the model (Carmines \& Zeller, 1979).

Then, the structural model is evaluated with paths coefficients, $R^{2}, f^{2}$, and $Q^{2}$. Path coefficients indicate the strength of direct relationships between constructs. According to Chin (1998) the determination values of coefficient $\left(R^{2}\right)$ approximately .670 substantial, around .333 average, and .190 weak. The effect size $\left(f^{2}\right)$ measures if an independent variable has a substantial impact on a dependent variable, values between .020-.150, between .150-.350, and exceeding .350 indicate a small, medium, and large effect (Chin, 1998; Cohen, 1988). The structural model's predictive relevance can be assessed with a nonparametric Stone-Geisser test $\left(Q^{2}\right.$; Geisser, 1975; Stone, 1974). The better the tested model's predictive relevance, the greater $Q^{2}$ becomes (Fornell $\&$ Cha, 1994).

\section{Results}

\subsection{Measurement Model}

The results of measurement model were presented in Table 1 which indicated that all item loadings ranged from 0.708 to 0.940 , and $\mathrm{p}$ value were all significant $(\mathrm{p}<.001)$. Composite reliability $(\mathrm{CR})$ and Cronbach alpha of constructs were larger than the proposed threshold .70 (Nunally \& Bernstein, 1994). Convergent validity which obtained by the average variance extracted (AVE) were larger than the proposed threshold .50 (Fornell \& Larcker, 1981). In addition, discriminant validity for constructs was obtained from (1) each indicator's loading is higher for its designated construct than for any of the other constructs, and each of the constructs loads highest with its assigned items (Chin, 1998) which was the case for all the indicators; (2) the square root of AVE were greater than the correlations between the construct and other constructs in the model (Fornell \& Larcker, 1981). Results in Table 2 show that all constructs have good discriminant validity. 
Table 1. Measurement results

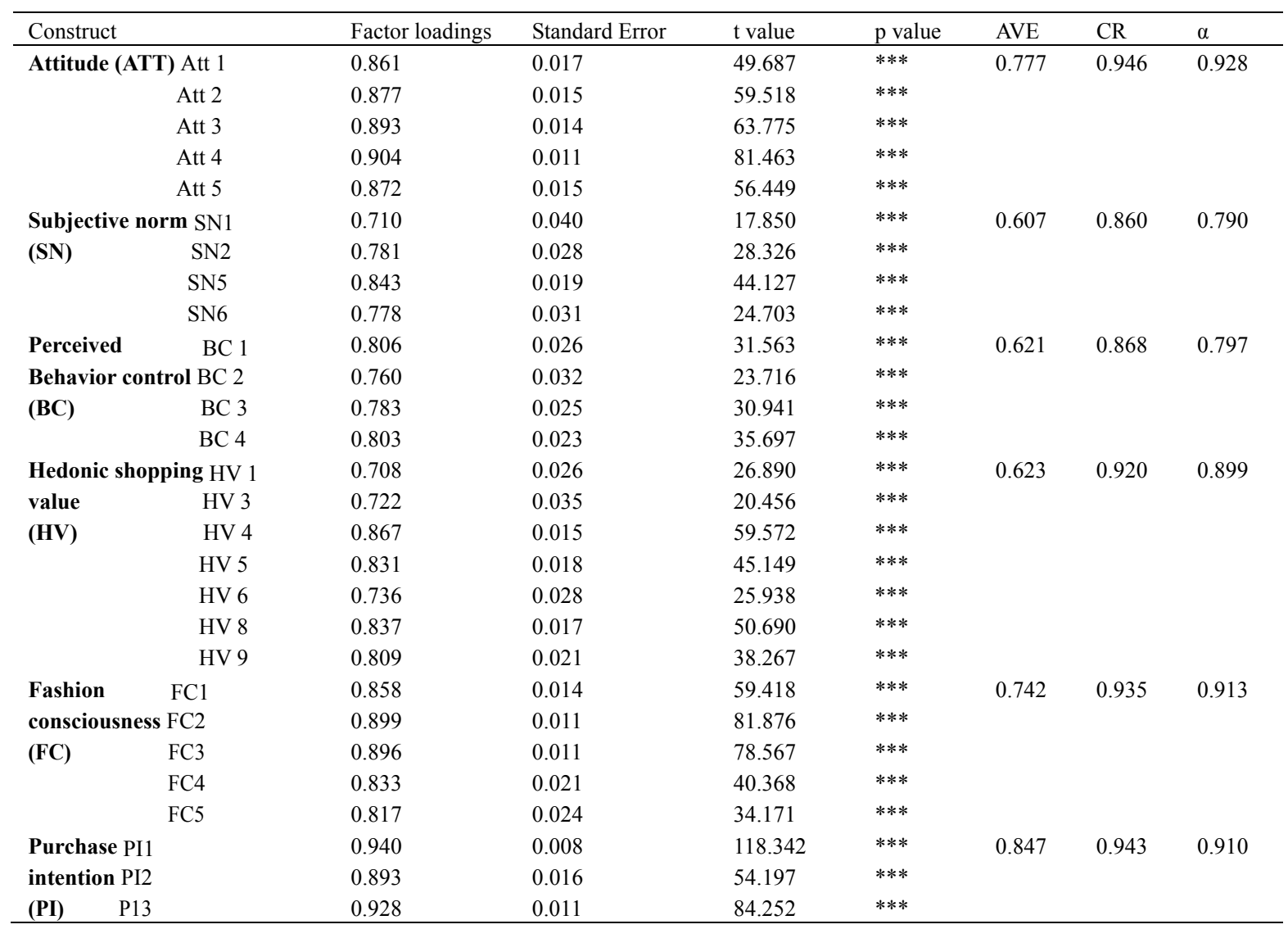

Note. $\mathrm{CR}=$ composite reliability.

Table 2. Correlation and discriminant validity analysis

\begin{tabular}{lllllll}
\hline & ATT & BC & FC & HV & PI & SN \\
\hline ATT & $\mathbf{0 . 8 8 1}$ & & & & & \\
BC & 0.339 & $\mathbf{0 . 7 8 8}$ & & & & \\
FC & 0.525 & 0.339 & $\mathbf{0 . 8 6 1}$ & & & \\
HV & 0.452 & 0.205 & 0.529 & $\mathbf{0 . 7 8 9}$ & & \\
PI & 0.640 & 0.511 & 0.531 & 0.385 & $\mathbf{0 . 9 2 0}$ & \\
SN & 0.526 & 0.247 & 0.422 & 0.305 & 0.448 & $\mathbf{0 . 7 7 9}$ \\
\hline
\end{tabular}

Note. Diagonal elements in boldface represent the square root of AVE.

\subsection{Structural Model}

The structural model and hypotheses were evaluated after attaining a validated measurement model. Our results in Table 3 presents assessment results which indicated we had average explanatory power $\left(R^{2}=0.542\right.$ and 0.423$)$. Five path coefficients are found to be significant at the .001 level with signs being in the expected direction. Others, two are significant at the .01 level, one is significant at the .05 level and one is insignificant. The effect size $\left(f^{2}\right)$ of each path in our research are counted for small effect, only hedonic shopping value through fashion consciousness, attitude toward purchase intention and behavior control to purchase intention have medium effects. Our $Q^{2}$ range from .147 (HV), .238 (FC), .349 (SN), .365 (BC) through .656 (ATT); means our DVs have predictive power. 
Table 3. Assessment results of research model

\begin{tabular}{llllll}
\hline & Path coefficients & SE & t value & $\boldsymbol{R}^{\mathbf{2}}$ & $\boldsymbol{f}^{\mathbf{2}}$ \\
\hline ATT -> PI & 0.390 & 0.047 & $8.313^{* * *}$ & 0.542 & 0.190 \\
SN -> PI & 0.088 & 0.042 & $2.104^{*}$ & & 0.011 \\
BC -> PI & 0.291 & 0.047 & $6.158^{* * *}$ & & 0.152 \\
HV -> PI & 0.030 & 0.044 & 0.678 & & 0.001 \\
FC -> PI & 0.175 & 0.055 & $3.204^{* *}$ & & 0.038 \\
ATT -> FC & 0.237 & 0.048 & $4.903^{* * *}$ & 0.423 & 0.059 \\
SN -> FC & 0.155 & 0.048 & $3.228^{* *}$ & & 0.030 \\
BC -> FC & 0.150 & 0.042 & $3.550^{* * *}$ & & 0.034 \\
HV -> FC & 0.344 & 0.050 & $6.860^{* * *}$ & & 0.159 \\
\hline
\end{tabular}

Note. $* \mathrm{p}<.05^{*}, * * \mathrm{p}<.01, * * * \mathrm{p}<.001$.

Finally, when examining the IVs of path coefficients in a PLS-SEM model with several layers, the indirect effects and their significance should also be identified and assessed. As far as the significance testing of indirect effects is concerned, one should first investigate whether the path coefficients between the IVs and the DV, between the IVs and the mediator, and between the mediator and the DV are statistically significant. If all path coefficients are significant, partial mediation existed. If an IV becomes insignificant when the mediator is added to the equation, full mediation is found (Baron \& Kenny, 1986). The significance of the indirect effects would then test by using the well-known Sobel's Z-statistic (Helm, Eggert, \& Garnefeld, 2010). H1a, b, H2a, b, H3a, b, $\mathrm{H} 4 \mathrm{a}, \mathrm{b}$, and $\mathrm{H} 5$ specify direct effects, while $\mathrm{H1c}, \mathrm{H} 2 \mathrm{c}, \mathrm{H} 3 \mathrm{c}, \mathrm{H} 4 \mathrm{c}$ predict mediational effects. The results are presented in Table 4; all IVs have significant positive influence on PI (H1a-H4a) and significant positive influence on the mediator, FC (H1b-H4b). In addition, the path coefficient between FC and PI is significant (H5). The direct process describes the direct effects of ATT, SN, BC and HV on FC and PI are all statistically significant, meant research hypotheses H1a, H1b, H2a, H2b, H3a, H3b, H4a, H4b, and H5 were supported. The indirect process represents the influence of IVs on FC, which in turn affects purchase intention. Results in Table 3 showed path coefficients are significant between ATT-PI $(\beta=0.390, p<.001)$, SN-PI $(\beta=0.088, p<.05)$, and BC-PI $(B=0.291, p<.001)$, indicated that FC has partial mediation between ATT, SN, BC and PI. The Sobel test statistic further confirms partial mediation $(\mathrm{ZATT}=5.067, \mathrm{ZSN}=5.067, \mathrm{ZBC}=5.067 ; \mathrm{p}<.05)$, supporting H1c, $\mathrm{H} 2 \mathrm{c}$, and H3c. Nevertheless, an insignificant path coefficient was found between HV-PI $(\beta=0.030, p>.001)$, indicated that FC fully mediates the relationship between HV and PI. The Sobel test statistic further confirms mediation $(\mathrm{ZHV}=6.405, \mathrm{p}<.05)$, supporting $\mathrm{H} 4 \mathrm{c}$.

Table 4. Direct effects and indirect effects of research model

\begin{tabular}{llllll}
\hline Casual path & Hypothesis & Path coefficients & SE & t value & Z \\
\hline ATT - PI & H1a & 0.426 & 0.047 & $9.086^{* * *}$ & \\
SN - > PI & H2a & 0.118 & 0.042 & $2.818^{* *}$ & \\
BC - > PI & H3a & 0.315 & 0.045 & $7.002^{* * *}$ & \\
HV - PI & H4a & 0.098 & 0.038 & $2.552^{*}$ & \\
ATT - F FC & H1b & 0.241 & 0.046 & $5.234^{* * *}$ & \\
SN - > FC & H2b & 0.159 & 0.047 & $3.401^{* *}$ & \\
BC - > FC & H3b & 0.154 & 0.043 & $3.550^{* * *}$ & \\
HV - > FC & H4b & 0.340 & 0.049 & $6.918^{* * *}$ & \\
FC - > PI & H5 & 0.531 & 0.043 & $12.423^{* * *}$ & \\
CATT-FC-PI & H1c & & & & $5.067^{*}$ \\
SN-FC-PI & H2c & & & & $3.535^{*}$ \\
BV-FC-PI & H3c & & & & $6.427^{*}$ \\
HV-FC-PI & H4c & & & & \\
\hline
\end{tabular}

\section{Discussion and Managerial Implications}

This research aimed to gain deeper understanding of consumers' fashion shoes purchase intention by extending an application of the TPB with mediating influence of fashion consciousness and addition IV, hedonic shopping value. Our results found that hedonic shopping value is related to behavioral intention which is in consistent with previous research (Chang, Burns, \& Francis, 2004; Davis, Lang, \& San Diego, 2014; Jones, Reynolds, \& Arnold, 2006). Our data further indicated that consumers' hedonic shopping value influence purchase intention of fashion shoes and fashion consciousness. Specifically, our finding indicated that consumers' fashion consciousness fully mediates the relationships between hedonic shopping value and purchase intention of fashion shoes. Thus, the fashion consciousness, which is merely the desire for and adoption of up-to-date styles to maintain one's status 
in a social network, is so impactful that it functions as an intervening factor between consumers' hedonic shopping value and purchase intentions. Moreover, similar to Kim and Chung (2011), our results showed that all TPB predictors significantly influenced consumers' purchase intention of fashion shoes. Precisely, consumers' fashion consciousness partially mediates the relationships between consumers' attitude, subjective norms and behavior control and their purchase intention of fashion shoes. In summary, individual's attitude, subjective norms, perceived behavioral control and hedonic shopping value toward fashion shoes would have direct impact to his/her purchase intention of fashion shoes. In addition, these four variables have indirect impacts through fashion consciousness to their purchase intention of fashion shoes.

This research provides valuable insights for fashion shoes retailers by indicating attitude is the most important determinant of purchase intention among the four predictors. The findings of this study suggest that creating a positive attitude toward purchasing fashion shoes may be a significant consideration for retailers to increase consumers' purchase intentions of fashion shoes. Specifically, given the impact of consumers' attitude, subjective norms, perceived behavior control and hedonic shopping value had on the purchase intention of fashion shoes, footwear retailers should invest resources in shopping circumstances to increase the hedonic shopping atmosphere and to cultivate favorable attitudes and increase perceived value. In addition, footwear retailers should develop advertisements to cultivate the acceptance of promising social norms of purchasing fashion shoes to customers. According to the results, the introduction of fashion consciousness as a mediator increases the influence of consumer attitude, subjective norms, control behavior and hedonic shopping value on purchase intention of fashion shoes, therefore, footwear retailers, in addition to focusing on design and value of their products, must also strive to establish designs in an up-to-date fashion manner.

\subsection{Limitations and Future Research}

Although the present findings provide a valuable insight for fashion shoes retailer, several suggestions for future research are made due to the study's limitations. First, most study participants in this research were female between the ages 26-35. Although female ages 26-35 is an appropriate age demographic for fashion shoes purchase behavior, future studies might examine whether differences exist between other age groups or gender in overall evaluations. In addition, this research is limited to fashion shoes category, findings may only be applicable to fashion merchandise categories; further study needs to obtain greater generalizability with variety of product categories. Additionally, since the mall-intercept method survey was used to collect data from Kaohsiung, a southern city in Taiwan, the findings of this study may not be applicable to all consumers in Taiwan or elsewhere. Thus, future research could incorporate online survey method which would allow samplings from various geographic locations. Finally, this study can be extended to be an international comparative study. Study found in this research shows subjective norm was a significant predictor for purchase intention of fashion shoes in Taiwan, whereas the attitude may overshadow the influence of subjective norm in other countries. It is important to explore the effect of attitude, subjective norms, perceived behavioral control, and hedonic shopping value on purchase intention varies in different cultures.

\section{References}

Ajzen, I. (1991). The theory of planned behavior. Organizational Behavior and Human Decision Processes, 50 , 179-211. https://doi.org/10.1016/0749-5978(91)90020-T

Ajzen, I., \& Madden, T. J. (1986). Prediction of goal-directed behavior attitude, intentions, and perceived behavioral control. Journal of Experimental Social Psychology, 22, 453-474. https://doi.org/10.1016/0022-1031(86)90045-4

Armitage, C. J., \& Conner, M. (2010). Efficacy of the theory of planned behaviour: A meta-analytic review. British Journal of Social Psychology, 40, 471-499. https://doi.org/10.1348/014466601164939

Arnold, M. J., \& Reynolds, K. E. (2003). Hedonic shopping motivations. Journal of Retailing, 79, 77-95. https://doi.org/10.1016/S0022-4359(03)00007-1

Arnold, M. J., \& Reynolds, K. E. (2009). Affect in Retail Shopping Experiences: Exploring the Role of Mood Regulation and Regulatory Focus. Journal of Retailing, 85, 308-320. https://doi.org/10.1016/j.jretai.2009.05.004

Babin, B. J., Darden, W. R., \& Griffin, M. (1994). Work and/or fun: Measuring hedonic and utilitarian shopping value. Journal of Consumer Research, 20, 644-656. https://doi.org/10.1086/209376

Back, K. W. (1985). Modernism and fashion: A social psychological interpretation. Lexington, MA: Lexington Books. 
Bagozzi, R. P., Baumgartner, J., \& Yi, Y. (1989). An investigation into the role of intentions as mediators of the attitude-behavior relationship. Journal of Economic Psychology, 10, 35-62. https://doi.org/10.1016/0167-4870(89)90056-1

Baron, R. M., \& Kenny, D. A. (1986). The moderator-mediator variable distinction in social psychological research: Conceptual, strategic and statistical considerations. Journal of Personality and Social Psychology, 51, 1173-1182. https://doi.org/10.1037//0022-3514.51.6.1173

Bellman, L. M., Teich, I., \& Clark, S. D. (2009). Fashion accessory buying intention among female millennials. Review of Business, 30, 46-57.

Bhattacherjee, A. (2000). Acceptance of e-commerce services: The case of electronic brokerages. IEEE Transactions on Systems, Man, and Cybernetics (Part A: Systems and Humans), 30(4), 411-420. https://doi.org/10.1109/3468.852435

Bian, Q., \& Forsythe, S. (2012). Purchase intention for luxury brand: A cross cultural comparison. Journal of Business Research, 65, 1443-1451. https://doi.org/10.1016/j.jbusres.2011.10.010

Blackwell, R., Miniard, P., \& Engel, F. (2000). Consumer behavior. Cincinnati: South-Western College Publishing.

Bordo, S. (1993). Unbearable weight: Feminism, western culture and the body. Berkeley, CA: University of California Press. https://doi.org/10.1002/(SICI)1099-1298(199911/12)9:6<481::AID-CASP546>3.0.CO;2-2

Boston Consulting Group. (2012). Driving growth: The female economic in China and India. BCG perspectives. Retrieved from https://www.bcgperspectives.com/content/articles/consumer_products_globalization_driving_growth_the_f emale_economy_in_china_and_india/

Canniere, M. H., Pelsmacker, P., \& Geuens, M. (2009). Relationship quality and the theory of planned behavior models of behavioral intentions and purchase behavior. Journal of Business Research, 62, 82-92. https://doi.org/10.1016/j.jbusres.2008.01.001

Carmines, E. G., \& Zeller, R. A. (1979). Reliability and Validity Assessment. London: Sage Publications. https://doi.org/10.4135/9781412985642

Carpenter, J. (2008). Consumer shopping value, satisfaction and loyalty in discount retailing. Journal of Retailing and Consumer Services, 15, 358-363. https://doi.org/10.1016/j.jretconser.2007.08.003

Chang, E., Burns, L. D., \& Francis, S. K. (2004). Gender differences in the dimensional structure of apparel shopping satisfaction among Korean consumers: The role of hedonic shopping value. Clothing and Textiles Research Journal, 22, 185-199. https://doi.org/10.1177/0887302X0402200404

Chen, M.-F., \& Tung, P.-J. (2014). Developing an extended Theory of Planned Behavior model to predict consumers' intention to visit green hotels. International Journal of Hospitality Management, 36, 221-230. https://doi.org/10.1016/j.ijhm.2013.09.006

Chen, W.-K., Chang, D.-S., \& Chen, C.-C. (2017). The role of utilitarian and hedonic values on users' continued usage and purchase intention in a social commerce environment. Journal of Economics and Management, 13(2), 193-220.

Chin, W. W. (1998). The Partial Least Squares Approach to Structural Equation Modeling. In G. A. Marcoulides (Ed.), Modern methods for business research (pp. 295-336). New Jersey: Lawrence Erlbaum.

Chin, W. W., Marcolin, B. L., \& Newsted, P. R. (2003). A Partial Least Squares latent variable modelling approach for measuring interaction effects: Results from a Monte Carlo Simulation Study and an electronic mail emotion/adoption study. Information Systems Research, 14, 189-217. https://doi.org/10.1287/isre.14.2.189.16018

Chouhan, N., \& Vig, H. (2020). Allied Market Research: Footwear Market by Type (Athletic and Nonathletic), Material (Leather and Non-leather), End User (Men, Women, and Children), and Distribution Channel (Hypermarket/Supermarket, Specialty Stores, Brand Outlets, Online Sales Channel, and Others): Global Opportunity Analysis and Industry Forecast, 2020-2027. Retrieved from https://www.alliedmarketresearch.com/footwear-market

Cohen, J. (1988). Statistical power analysis for the behavioral sciences. Hillsdale, NJ: Lawrence Erlbaum.

Cowart, K. O., \& Goldsmith, R. E. (2007). The influence of consumer decision-making styles on online apparel 
consumption by college students. International Journal of Consumer Studies, 31, 639-647. https://doi.org/10.1111/j.1470-6431.2007.00615.x

Culiberg, B. (2014). Towards an understanding of consumer recycling from an ethical perspective. International Journal of Consumer Studies, 38, 90-97. https://doi.org/10.1111/ijcs.12068

Davis, R. A., Lang, B., \& San Diego, J. (2014). How gender affects the relationship between hedonic shopping motivation and purchase intentions? Journal of Consumer Behaviour, 13, 18-30. https://doi.org/10.1002/cb.1450

Eagly, A. H., \& Chaiken, S. (1993). The psychology of attitudes. San Diego: Harcourt Brace Jovanovich.

Epuran, G., Gârdan, I. P., Gârdan, D. A., \& Bumbas, F. (2015). Hedonic value of clothing products/Valoarea hedonica a produselor vestimentare. Industria Textila, 66(3), 164.

Executive Yuan. (2020). National Statistics. Human resources investigation in gender topic. Retrieved March 16, 2020, from https://www.stat.gov.tw/public/Attachment/9325165717J2042CJ5.pdf

Fernandes, C. (2013). Analysis of counterfeit fashion purchase behavior in UAE. Journal of Fashion Marketing and Management, 17, 85-97. https://doi.org/10.1108/13612021311305155

Fielding, K. S., Terry, D. J., Masser, B. M., \& Hogg, M. A. (2008). Integrating social identity theory and the theory of planned behaviour to explain decisions to engage in sustainable agricultural practices. British Journal of Social Psychology, 47, 23-48. https://doi.org/10.1348/014466607X206792

Fishbein, M., \& Ajzen, I. (1975). Belief, attitude, intention, and behavior: An introduction to theory and research. Reading, MA: Addison-Wesley.

Fogel, J., \& Zachariah, S. (2017). Intention to us Yelp review Website and purchase behavior after reading reviews. Journal of Theoretical and Applied Electronic Commerce Research, 12(1), 53-67. https://doi.org/10.4067/S0718-18762017000100005

Fornell, C., \& Cha, J. (1994). Partial least squares. In R. P. Bagozzi (Ed.), Advanced Methods of Marketing Research (pp. 152-178). Cambridge: Blackwell.

Fornell, C., \& Larcker, D. F. (1981). Evaluating structural equation models with unobservable variables and measurement error. Journal of Marketing Research, 18, 39-50. https://doi.org/10.2307/3151312

Future Market Insights. (2018). Womens Footwear Market: Women's Footwear Market: Manufacturers Offering Diversified and Innovative Products to Expand Customer Base: Global Industry Analysis 2013-2017 and Opportunity Assessment 2018-2027. An Incisive, In-depth Analysis on the Womens Footwear Market. Retrieved from https://www.futuremarketinsights.com/reports/womens-footwear-market

Geisser, S. (1975). The predictive sample reuse method with applications. Journal of the American Statistical Association, 70, 320-328. https://doi.org/10.1080/01621459.1975.10479865

Goldsmith, R. E., Flynn, L. R., \& Kim, D. (2010). Status consumption and price sensitivity. Journal of Marketing Theory and Practice, 18(4), 323-338. https://doi.org/10.2753/MTP1069-6679180402

Grand View Research. (2019). Footwear Market Size, Share \& Trends Analysis Report By Type (Athletic, Non Athletic), By End User (Men, Women, Children), By Region (North America, MEA, APAC, Europe, Central \& South America), And Segment Forecasts, 2019-2025. Retrieved from https://www.grandviewresearch.com/industry-analysis/footwear-market

Gutman, J., \& Mills, M. K. (1982). Fashion life cycle, self-concept, shopping orientation, and store patronage: an integrative analysis. Journal of Retailing, 58(2), 64-87.

Hassan, S. H., \& Harun, H. (2016). Factors influencing fashion consciousness in hijab fashion consumption among hijabistas. Journal of Islamic Marketing, 7(4), 476-494. https://doi.org/10.1108/JIMA-10-2014-0064

Helm, S., Eggert, A., \& Garnefeld, I. (2010). Modeling the Impact of Corporate Reputation on Customer Satisfaction and Loyalty Using Partial Least Squares. In V. V. Esposito, W. Chin, J. Henseler \& H. Wang (Eds.), Handbook of Partial Least Squares: Concepts, Methods and Applications in Marketing and Related Fields. Springer Handbooks of Computational Statistics (pp. 691-711). Berlin/Heidelberg: Springer. https://doi.org/10.1007/978-3-540-32827-8_23

Hourigan, S. R., \& Bougoure, U.-S. (2012). Towards a better understanding of fashion clothing involvement. Australasian Marketing Journal, 20(2), 127-135. https://doi.org/10.1016/j.ausmj.2011.10.004 
Industrial Development Bureau. (2011). 2011 Global footwear markets development and shoes material trends analysis. Ministry of Economic Affairs. Retrieved from http://www.tipo.org.tw/docs/fup/2_2011\%E5\%85\%A8\%E7\%90\%83\%E9\%9E\%8B\%E6\%A5\%AD\%E7\%9 9\%BC\%E5\%B1\%95\%Е5\%80\%8B\%E8\%AB\%96\%Е8\%88\%87\%Е9\%9E\%8B\%E6\%9D\%90\%Е8\%B6\%A $8 \% \mathrm{E} 5 \% 8 \mathrm{~B} \% \mathrm{A2} \% \mathrm{E} 5 \% 88 \% 86 \% \mathrm{E} 6 \% 9 \mathrm{E} \% 90$.pdf

Jackson, V., Stoel, L., \& Brantley, A. (2011). Mall attributes and shopping value: Differences by gender and generational cohort. Journal of Retailing and Consumer Services, 18(1), 1-9. https://doi.org/10.1016/j.jretconser.2010.08.002

Jones, M. A., Reynolds, K. E., \& Arnold, M. (2006). Hedonic and utilitarian shopping value: Investigating differential effects on retail outcomes. Journal of Business Research, 59, 974-981. https://doi.org/10.1016/j.jbusres.2006.03.006

Kim, H., \& Karpova, E. (2010). Consumer attitudes toward fashion counterfeits: Application of the Theory of planned behavior. Clothing and Textiles Research Journal, 28, 79-94. https://doi.org/10.1177/0887302X09332513

Kim, H. Y., \& Chung, J.-E. (2011). Consumer purchase intention for organic personal care products. Journal of Consumer Marketing, 28, 40-47. https://doi.org/10.1108/07363761111101930

Lertwannawit, A., \& Mandhachitara, R. (2012). Interpersonal effects on fashion consciousness and status consumption moderated by materialism in metropolitan men. Journal of Business Research, 65, 1408-1416. https://doi.org/10.1016/j.jbusres.2011.10.006

Mathwick, C., Malhotra, N., \& Rigdon, E. (2001). Experiential value: Conceptualization, measurement and application in the catalog and internet shopping environment. Journal of Retailing, 77(1), 39-56. https://doi.org/10.1016/S0022-4359(00)00045-2

Nam, J., Reagan, H., Gam, H. J., Kang, J. H., Kim, J., Kumphai, P., ... Lynne, R. (2007). The fashion-conscious behaviours of mature female consumers. International Journal of Consumer Studies, 31, 102-108. https://doi.org/10.1111/j.1470-6431.2006.00497.x

Noble, S. M., Griffith, D., \& Adjei, M. T. (2006). Drivers of Local Merchant Loyalty: Understanding the Influence of Gender and Value Orientation. Journal of Retailing, 82, 177-188. https://doi.org/10.1016/j.jretai.2006.05.002

Nunnally, J. C., \& Bernstein, I. H. (1994). Psychometric Theory. New York: McGraw-Hill.

O'Keeffe, L. (1996). Shoes: A celebration of pumps, sandals, slippers and more. New York: Workman.

Parker, R. S., Hermans, C. M., \& Schaefer, A. D. (2004). Fashion consciousness of Chinese, Japanese and American teenagers. Journal of Fashion Marketing and Management, 8, 176-186. https://doi.org/10.1108/13612020410537870

Shim, S., \& Gehrt, K. C. (1996). Hispanic and Native American adolescents: An exploratory study of their approach to shopping. Journal of Retailing, 72, 307-324. https://doi.org/10.1016/S0022-4359(96)90032-9

Stone, M. (1974). Cross-validatory choice and assessment of statistical predictions. Journal of the Royal Statistical Society, 36, 111-133. https://doi.org/10.1111/j.2517-6161.1974.tb00994.x

Taylor, S., \& Todd, P. A. (1995). Understanding information technology usage: A test of competing models. Information Systems Research, 6, 144-176. https://doi.org/10.1287/isre.6.2.144

Vermeir, I., \& Verbeke, W. (2008). Sustainable food consumption among young adults in Belgium: Theory of planned behaviour and the role of confidence and values. Ecological Economics, 64, 542-553. https://doi.org/10.1016/j.ecolecon.2007.03.007

Yang, K. (2012). Consumer technology traits in determining mobile shopping adoption: An application of the extended theory of planned behavior. Journal of Retailing and Consumer Services, 19, 484-491. https://doi.org/10.1016/j.jretconser.2012.06.003

Zhou, R. (2014). Euromonitor International. Global footwear market: Trends, developments and prospects (PowerPoint slides). Asia-Pacific Sole Materials Summit 2014. June 18th, 2014. Guangzhour, China. Global Footwear Market Trends, Developments and Prospects. Retrieved from https://www.slideshare.net/Euromonitor/global-footwear-market-trends-developments-and-prospects 


\section{Copyrights}

Copyright for this article is retained by the author, with first publication rights granted to the journal.

This is an open-access article distributed under the terms and conditions of the Creative Commons Attribution license (http://creativecommons.org/licenses/by/4.0/). 